\title{
ON PRESERVATION AND DEVELOPMENT OF ESTONIAN AS A RESEARCH LANGUAGE IN ANTHROPOLOGY - THE ROLE OF THE YEARBOOKS OF THE ESTONIAN ANTHROPOMETRIC REGISTER (1998-2002) IN IT. PART II
}

\author{
JaAn Kasmel, TiIU Kasmel \\ Centre for Physical Anthropology, University of Tartu, Tartu, Estonia
}

\begin{abstract}
On 18 July 2018, the Centre for Physical Anthropology at the University of Tartu will mark its 25th anniversary. The specialists of different research areas from whole Estonia who had gathered around this Centre also considered it necessary to preserve and develop Estonian as a research language in anthropology. When cooperation was established with the Estonian Anthropometric Register (founded in 1995), it became possible to publish the Estonian-language Yearbook of the Estonian Anthropometric Register (YEAR), the first of which was published in 1998, i.e. 20 years ago.

The article will deal with the YEARs published in 1998-2002 - who were the authors who decided to publish their research papers on anthropology in in Estonian in this serial, how many of them there were, in which towns and institutions they worked?

The first part of the overview [6] briefly described the publications by researchers of anthropology originating in Estonia, starting with publications in Latin and finishing with English as the main present-day language of research. Table 1 provided a general characterisation of the five yearbooks and Table 2 the distribution of the published articles according to the number of authors.

Tables 3-7 in the second part of the overview present the distribution of articles over the years according to their first authors. Table 8 presents the distribution of articles between Tartu and Tallinn and the institutions and their subunits in these towns according to the first authors of the articles.
\end{abstract}

Keywords: Centre for Physical Anthropology at the University of Tartu; Yearbooks of the Estonian Anthropometric Register; Estonian as research language in anthropology 


\section{PART II}

The first part of the overview on this theme was published in the journal Papers on Anthropology XXVI/1, 2017 (pp. 28-40). Here is its second part.

Based on the contents pages of the Yearbooks of the Estonian Anthropometric Register 1998-2002, Tables 3-7 where compiled, which show the distribution of articles over the years according to their first authors.

Table 3 shows the distribution of articles published in five YEARs (1998-2002) $[1,2,3,4,5]$ according to their first authors starting from 1998. The first column of the Table gives, after the numbers, the authors' names in alphabetical order; column 2 presents the number of articles published in YEAR in 1998; columns 3-6 show the number of articles published in YEARs respectively in 1999-2002; column 7 shows the total number of articles by each first author in five YEARs.

Table 3. Number of articles published in YEARs according to first authors, 1998-2002

\begin{tabular}{lcccccc}
$\begin{array}{c}\text { 1st author } \\
\text { of the article } \\
\text { published in YEAR }\end{array}$ & $\mathbf{1 9 9 8}$ & $\mathbf{1 9 9 9}$ & $\mathbf{2 0 0 0}$ & $\mathbf{2 0 0 1}$ & $\mathbf{2 0 0 2}$ & $\begin{array}{c}\text { Total of articles in } \\
\text { five YEARs according } \\
\text { to each 1st author }\end{array}$ \\
\hline 1. Heapost, Leiu & 1 & $\mathbf{2}$ & 1 & 1 & 1 & $\mathbf{6}$ \\
\hline 2. Kaarma, Helje & 1 & - & 1 & - & - & 2 \\
\hline 3. Kaldmäe, Pille & 1 & 1 & - & - & 1 & 3 \\
\hline 4. Kalling, Ken & 1 & - & - & - & - & 1 \\
\hline 5. Kask, Virve & 1 & - & - & - & - & 1 \\
\hline 6. Kasmel, Jaan & $\mathbf{2}$ & 1 & 1 & 1 & 1 & $\mathbf{6}$ \\
\hline 7. Kirss, Ülle & 1 & 1 & 1 & 1 & - & $\mathbf{4}$ \\
\hline 8. Kums, Tatjana & 1 & - & - & - & - & 1 \\
\hline 9. Landõr, Anatoli & 1 & 1 & - & - & - & 3 \\
\hline 10. Lintsi, Mart & 1 & 1 & 1 & 1 & 1 & $\mathbf{5}$ \\
\hline 11. Loko, Jaan & 1 & 1 & 1 & 1 & 1 & 3 \\
\hline 12. Loolaid, Kersti & 1 & 1 & - & 1 & - & $\mathbf{5}$ \\
\hline 13. Maiste, Eevi & 1 & 1 & 1 & 1 & 1 & 2 \\
\hline 14. Oja, Leila & 1 & 1 & - & - & - & 3 \\
\hline 15. Parve, Valdar & 1 & - & - & - & - & 2 \\
\hline 16. Peterson, Jana & 1 & 1 & 1 & - & - & - \\
\hline 17. Pihl, Eve & 1 & - & 1 & - & - & 3 \\
\hline
\end{tabular}




\begin{tabular}{lcccccc}
\hline $\begin{array}{c}\text { 1st author } \\
\text { of the article } \\
\text { published in YEAR }\end{array}$ & $\mathbf{1 9 9 8}$ & $\mathbf{1 9 9 9}$ & $\mathbf{2 0 0 0}$ & $\mathbf{2 0 0 1}$ & $\mathbf{2 0 0 2}$ & $\begin{array}{c}\text { Total of articles in } \\
\text { five YEARs according } \\
\text { to each 1st author }\end{array}$ \\
\hline 18. Saava, Merileid & $\mathbf{2}$ & - & - & - & - & 2 \\
\hline 19. Stamm, Raini & 1 & 1 & 1 & 1 & 1 & $\mathbf{5}$ \\
\hline 20. Suurorg, Lagle & 1 & - & - & 1 & 1 & 3 \\
\hline 21. Tellmann, Alvi & 1 & 1 & 1 & - & - & 3 \\
\hline 22. Tiit, Ene-Margit & 1 & - & 1 & $\mathbf{2}$ & 1 & $\mathbf{5}$ \\
\hline 23. Varjas, Juta & 1 & - & - & - & - & 1 \\
\hline 24. Veldre, Gudrun & 1 & 1 & - & 1 & 1 & $\mathbf{4}$ \\
\hline 25. Volož, Olga & 1 & 1 & - & - & - & 2 \\
\hline $\begin{array}{l}\text { Total of articles in } \\
\text { each YEAR }\end{array}$ & 27 & 16 & 12 & 12 & 11 & $\begin{array}{c}\text { 78 articles in total in five } \\
\text { YEARs by 1st authors who } \\
\text { started in 1998 }\end{array}$ \\
\hline
\end{tabular}

In Table 3 we can see that, as revealed by numbers in column 1 before the names of the first authors, 25 authors have presented their publications in YEAR 1998; in the following four yearbooks, 1999-2002; these authors have been the first authors of $15,12,11$ and 11 articles respectively.

From the authors who started publishing their articles in YEAR 1998, there are 78 publications in total in the five yearbooks under observation. According to years, there are respectively $27,16,12,12$ and 11 articles.

Table 3 reveals that some first authors (J. Kasmel, M. Saava, L. Heapost and E.-M. Tiit) published two articles in 1998, 1999 and 2001.

Two first authors (L. Heapost and J. Kasmel) both published six publications in the five yearbooks under observation; five first authors (M. Lintsi, J. Loko, E. Maiste, R. Stamm and E.-M. Tiit) each published five publications two first authors (Ü. Kirss and G. Veldre) four publications each.

Six first authors (P. Kaldmäe, A. Landõr, K. Loolaid, J. Peterson, L. Suurorg and A. Tellmann) published three publications each; five first authors $(\mathrm{H}$. Kaarma, L. Oja, E. Pihl, M. Saava and O. Volož) - two publications each, and five first authors (K. Kalling, V. Kask, T. Kums, V. Parve and J. Varjas) - one publication each in the five YEARs under observation. 
Table 4 shows the distribution of articles in four YEARs (1999-2002) [2, 3, 4, 5] according to first authors who were added in 1999. The first column of the Table presents their names in alphabetical order after the numbers.

Column 2 in this Table remains empty, as the articles according to their first authors have been added from 1999.

Column 3 shows the number of articles according to first authors published in YEAR in 1999.

Columns 4-6 show the number of articles published articles in YEARs in 2000-2002 respectively.

Column 7 presents the total number of published articles according to their 1 st authors in five YEARs.

Table 4. Number of articles published in YEARs according to first authors, 1999-2002

\begin{tabular}{lcccccc}
\hline $\begin{array}{c}\text { 1st author } \\
\text { of the article } \\
\text { published in YEAR }\end{array}$ & 1998 & 1999 & 2000 & 2001 & 2002 & $\begin{array}{c}\text { Total of articles in five } \\
\text { YEARs according to each } \\
\text { 1st author }\end{array}$ \\
\hline 1. Allmäe, Raili & - & 1 & - & - & - & 1 \\
\hline 2. Jürimäe, Jaak & - & 2 & 1 & 1 & 1 & 5 \\
\hline 3. Kongo, Linda & - & 1 & - & 1 & 1 & 3 \\
\hline 4. Leppik, Aire & - & 1 & - & - & 1 & 2 \\
\hline 5. Sarap, Galina & - & 1 & - & - & - & 1 \\
\hline 6. Tammiksaar, Erki & - & 1 & - & - & - & 1 \\
\hline 7. Vatter, Enn & - & 1 & - & - & - & 1 \\
\hline $\begin{array}{l}\text { Total of articles in } \\
\text { each YEAR }\end{array}$ & - & 8 & 1 & 2 & 3 & $\begin{array}{l}\text { 14 articles in total in five } \\
\text { YEARs according to 1st } \\
\text { authors added in 1999 }\end{array}$ \\
\hline
\end{tabular}

In 1999, seven new first authors appeared in YEAR, and they published eight articles this year.

In the following years, 2000-2002, respectively 1, 2 and 3 publications appeared from them.

For the five yearbooks, the first authors who appeared in 1999 wrote 14 articles.

Among them, one first author (J. Jürimäe) published five articles, one first author (L. Kongo) three and one 1st author (A. Lepp) - two articles. Four first authors (R. Allmäe, G. Sarap, E. Tammiksaar and E. Vatter) published one publication each. 
Table 5 shows the distribution of articles in three YEARs (2000-2002) [3, 4, 5] according to the new first authors of 2000. The first column of the Table presents their names in alphabetical order after the numbers.

Columns 2 and 3 in this Table remain empty, as the articles according to their 1st authors have been added from 2000.

Column 4 shows the number of articles according to first authors published in YEAR in 2000.

Columns 5-6 show the number of articles published in YEARs in 20012002 respectively.

Column 7 presents the total number of published articles according to first authors in five YEARs.

Table 5. Number of articles published in YEARs according to first authors, 2000-2002

\begin{tabular}{lcccccc}
\hline $\begin{array}{c}\text { 1st author } \\
\text { of the article } \\
\text { published in YEAR }\end{array}$ & 1998 & 1999 & 2000 & 2001 & 2002 & $\begin{array}{c}\text { Total of articles in five } \\
\text { YEARs according to each } \\
\text { 1st author }\end{array}$ \\
\hline 1. Bakler, Tiia & - & - & 1 & - & - & 1 \\
\hline 2. Jürimäe, Toivo & - & - & 1 & 1 & 1 & 3 \\
\hline 3. Lilienberg, Karin & - & - & 1 & 1 & 1 & 3 \\
\hline 4. Mäestu, Jaak & - & - & 1 & - & - & 1 \\
\hline 5. Rehand, Merle & - & - & 1 & - & - & 1 \\
\hline 6. Simovart, Helle-Evi & - & - & 1 & - & - & 1 \\
\hline 7. Visnapuu, Milvi & - & - & 1 & - & 1 & 2 \\
\hline 8. Õun, Kandela & - & - & 1 & 1 & - & 2 \\
\hline $\begin{array}{l}\text { Total of articles in } \\
\text { each YEAR }\end{array}$ & - & - & 8 & 3 & 3 & $\begin{array}{c}\text { 14 articles in total in five } \\
\text { YEARs according to 1st } \\
\text { authors added in 2000 }\end{array}$ \\
\hline
\end{tabular}

In 2000, eight new first authors appeared in YEAR, and they published eight articles this year.

In the following years, 2001 and 2002, respectively 3 and 3 publications appeared from them.

In the five yearbooks, the first authors who appeared in 2000 published 14 articles.

Among them, two first authors (J. Jürimäe and K. Lilienberg) published three articles each, two first authors (M. Visnapuu and K. Oun) - two articles each, and four first authors (T. Bakker, J. Mäestu, M. Rehand and H.-E. Simovart) - one article each. 
Table 6 shows the distribution of articles in two YEARs (2001-2002) $[4,5]$ according to the first authors who were added in 2001. The first column of the Table presents their names in alphabetical order after the numbers.

Columns 2-4 in this Table remain empty, as the articles according to their first authors have been added from 2001.

Column 5 shows the number of articles according to first authors published in YEAR in 2001.

Column 6 shows the number of articles according to first authors published in YEAR in 2002.

Column 7 presents the total number of published articles according to first authors in five YEARs.

Table 6. Number of articles published in YEARs according to first authors, 2001-2002

\begin{tabular}{|c|c|c|c|c|c|c|}
\hline $\begin{array}{c}\text { 1st author of } \\
\text { the article } \\
\text { published in YEAR }\end{array}$ & 1998 & 1999 & 2000 & 2001 & 2002 & $\begin{array}{c}\text { Total of articles in five } \\
\text { YEARs according to each } \\
\text { 1st author }\end{array}$ \\
\hline 1. Aunapuu, Marina & & & & 1 & - & 1 \\
\hline 2. Haljaste, Kaja & & & & 1 & - & 1 \\
\hline 3. Järvelaid, Mari & & & & 2 & - & 2 \\
\hline 4. Kiisk, Liidia & & & & 1 & - & 1 \\
\hline 5. Lehto, Kristi & & & & 1 & - & 1 \\
\hline 6. Limbo, Jana & & & & 1 & - & 1 \\
\hline 7. Rahe, Kerttu & & & & 1 & - & 1 \\
\hline 8. Toomsalu, Maie & & & & 1 & 2 & 1 \\
\hline $\begin{array}{l}\text { Total of articles in } \\
\text { each YEAR }\end{array}$ & & & & 9 & 2 & $\begin{array}{l}11 \text { articles in total in five } \\
\text { YEARs according to } 1 \mathrm{st} \\
\text { authors added in } 2001\end{array}$ \\
\hline
\end{tabular}

In 2001, eight new first authors appeared in YEAR, and they published nine articles this year. Among them, one first author (M. Järvelaid) published two articles.

In the YEAR of the following year, one first author (M. Toomsalu) published two articles.

By the first authors who appeared in 2001, 11 articles in total were published in five yearbooks under observation.

Among them, one first author ( $\mathrm{M}$. Toomsalu) published three articles, one first author (M. Järvelaid) - two articles, and six first authors (M. Aunapuu, K. Haljaste, L. Kiisk, K. Lehto, J. Limbo, K. Rahe) - one article each. 
Table 7 shows the distribution of articles in one YEAR (2002) [5] according to first authors who were added in 2002. The first column of the Table presents their names in alphabetical order after the numbers.

Columns $2-5$ in this Table remain empty, as the articles according to their first authors have been added from 2002.

Column 6 shows the number of articles according to first authors published in YEAR in 2002.

Column 7 presents the total number of published articles according to first authors in five YEARs.

Table 7. Number of articles published in YEAR 2002 according to first authors

\begin{tabular}{|c|c|c|c|c|c|c|}
\hline $\begin{array}{c}\text { 1st author of } \\
\text { the article } \\
\text { published in YEAR }\end{array}$ & 1998 & 1999 & 2000 & 2001 & 2002 & $\begin{array}{c}\text { Total of articles in five } \\
\text { YEARs according to each } \\
\text { 1st author }\end{array}$ \\
\hline 1. Born, Liivika & & & & & 1 & 1 \\
\hline 2. Johanson, Ege & & & & & 1 & 1 \\
\hline 3. Ohvril, Kadri & & & & & 1 & 1 \\
\hline 4. Pääsuke, Mati & & & & & 1 & 1 \\
\hline 5. Rosenthal, Merle & & & & & 1 & 1 \\
\hline 6. Russak, Silvia & & & & & 1 & 1 \\
\hline 7. Salundi, Urve & & & & & 1 & 1 \\
\hline 8. Saluste, Liidia & & & & & 1 & 1 \\
\hline $\begin{array}{l}\text { Total of articles in } \\
\text { each YEAR }\end{array}$ & & & & & 8 & $\begin{array}{l}8 \text { articles in total in five } \\
\text { YEARs according to } 1 \mathrm{st} \\
\text { authors added in } 2002\end{array}$ \\
\hline
\end{tabular}

In 2002, eight new first authors appeared in YEAR, and they published eight articles this year. Their total contribution to the five yearbooks is eight articles.

Each of the eight first authors (L. Born, E. Johanson, K. Ohvril, M. Pääsuke, M. Rosenthal, S. Russak, U. Salundi and the L. Saluste) published one publication.

Next, an overview is presented of the distribution of the articles published in the Yearbooks of the Estonian Anthropometric Register in 1998-2002 [1, 2, 3, $4,5]$ between Tartu and Tallinn and the workplaces of the first authors (institutions and their subunits). 
For that, the institution where the first author worked and its subunit and the town where the institution was situated were taken from the yearbooks in the order of their publication.

Based on this, two-part Table 8 was compiled, as the first authors come from two towns only: a) Tartu and b) Tallinn.

The first column of Table 8 includes the institutions and their subunits where the first authors worked. The numbers of articles published in YEARs 1998-2002 according to the workplaces and their subunits of first authors are given in columns 2-6. Column 7 shows the total number of articles in five YEARs according to the workplaces/subunits of the first authors.

Table 8. Distribution of articles published in the Yearbooks of the Estonian Anthropometric Register (1998-2002) between Tartu and Tallinn and the institutions and subunits where the first authors worked

\section{a. First authors from Tartu}

\begin{tabular}{|c|c|c|c|c|c|c|}
\hline $\begin{array}{l}\text { Yearbook of the Estonian } \\
\text { Anthropometric Register }\end{array}$ & 1998 & 1999 & 2000 & 2001 & 2002 & $\begin{array}{l}\text { Total of articles } \\
\text { from institutions } \\
\text { of Tartu and } \\
\text { their subunits in } \\
\text { five YEARs }\end{array}$ \\
\hline \multicolumn{7}{|l|}{ University of Tartu } \\
\hline $\begin{array}{l}\text { 1. Subunit not mentioned (not } \\
\text { presented by } 1 \text { st author) }\end{array}$ & 2 & 1 & - & - & - & 3 \\
\hline 2. History Museum & 1 & - & - & - & - & 1 \\
\hline 3. Institute of Anatomy & - & - & 1 & 1 & - & 2 \\
\hline 4. Chair of Integrative Zoology & - & - & - & 1 & - & 1 \\
\hline 5. Institute of Pharmacology & - & - & - & 1 & 2 & 3 \\
\hline 6. Department of Philosophy & 1 & - & - & - & - & 1 \\
\hline $\begin{array}{l}\text { 7. Centre for Physical } \\
\text { Anthropology }\end{array}$ & 5 & 5 & 6 & 5 & 5 & 26 \\
\hline 8. Faculty of Physical Education & 1 & - & - & 1 & - & 2 \\
\hline $\begin{array}{l}\text { 9. Institute of Mathematical } \\
\text { Statistics }\end{array}$ & 1 & - & 1 & 3 & 1 & 6 \\
\hline $\begin{array}{l}\text { 10. Chair of Polyclinic and } \\
\text { Family Medicine }\end{array}$ & - & - & - & 2 & - & 2 \\
\hline 11. Institute of Exercise Biology & - & - & - & - & 3 & 3 \\
\hline 12. Sports Centre & - & - & 2 & - & 1 & 3 \\
\hline 13. Institute of Sport Pedagogy & 3 & 5 & 6 & 5 & 5 & 24 \\
\hline $\begin{array}{l}\text { 14. Institute of Zoology and } \\
\text { Hydrobiology }\end{array}$ & 1 & 1 & - & 1 & 1 & 4 \\
\hline
\end{tabular}




\begin{tabular}{|c|c|c|c|c|c|c|}
\hline $\begin{array}{l}\text { Yearbook of the Estonian } \\
\text { Anthropometric Register }\end{array}$ & 1998 & 1999 & 2000 & 2001 & 2002 & $\begin{array}{l}\text { Total of articles } \\
\text { from institutions } \\
\text { of Tartu and } \\
\text { their subunits in } \\
\text { five YEARs }\end{array}$ \\
\hline \multicolumn{7}{|l|}{ Tartu University Hospital } \\
\hline 1. Cardiology Clinic of TU Hospital & 1 & 1 & 2 & 1 & 1 & 6 \\
\hline 2. Children's Clinic of TU Hospital & - & - & - & - & 1 & 1 \\
\hline 3. Women's Clinic of TU Hospital & 1 & - & - & - & - & 1 \\
\hline 4. Psychiatry Clinic of TU Hospital & 1 & - & - & - & - & 1 \\
\hline $\begin{array}{l}\text { 5. Sports Medicine and Rehabilita- } \\
\text { tion Clinic of TU Hospital }\end{array}$ & 1 & - & - & - & 1 & 2 \\
\hline 6. Dentistry Clinic of TU Hospital & - & - & - & - & - & 1 \\
\hline 7. Catering Service of TU Hospital & - & - & - & 1 & - & 1 \\
\hline Baer Museum & - & 1 & - & - & - & 1 \\
\hline Estonian Naturalists' Society & - & 1 & - & 1 & 1 & 3 \\
\hline Articles from Tartu in each YEAR & 19 & 15 & 18 & 23 & 23 & \\
\hline $\begin{array}{l}\text { Articles from Tartu in five YEARs in } \\
\text { total }\end{array}$ & & & & & & 98 \\
\hline
\end{tabular}

\section{b. First authors from Tallinn}

\begin{tabular}{|c|c|c|c|c|c|c|}
\hline $\begin{array}{l}\text { Yearbook of the Estonian } \\
\text { Anthropometric Register }\end{array}$ & 1998 & 1999 & 2000 & 2001 & 2002 & $\begin{array}{l}\text { Articles from } \\
\text { Tallinn in five } \\
\text { YEARs in total }\end{array}$ \\
\hline Institute of History & 1 & 5 & 1 & 1 & 1 & 9 \\
\hline Estonian Institute of Cardiology & 3 & 1 & 1 & 1 & 2 & 8 \\
\hline $\begin{array}{l}\text { Estonian Bureau of Medical } \\
\text { Statistics }\end{array}$ & 1 & - & - & - & - & 1 \\
\hline $\begin{array}{l}\text { Institute of Experimental and } \\
\text { Clinical Medicine }\end{array}$ & - & 1 & 1 & - & - & 2 \\
\hline $\begin{array}{l}\text { Informatics Department of the } \\
\text { Ministry of Social Affairs }\end{array}$ & - & 1 & - & - & - & 1 \\
\hline Tallinn Nõmme Children's Hospital & 2 & 1 & - & 1 & 1 & 5 \\
\hline Health Protection Inspectorate & 1 & - & - & - & - & 1 \\
\hline Articles from Tallinn in each YEAR & 8 & 9 & 3 & 3 & 4 & \\
\hline $\begin{array}{l}\text { Articles from Tallinn in five YEARs } \\
\text { in total }\end{array}$ & & & & & & 37 \\
\hline
\end{tabular}


Part a of Table 8 shows that the first authors working in institutions and their subunits situated in Tartu published a total of 98 articles in five YEARs. They were distributed between the five YEARs as follows: 19, 15, 18, 23 and 23 articles.

From the University of Tartu and its 13 subunits, the greatest number of publications came from the researchers directly related to the Centre for Physical Anthropology. The articles were distributed between the five YEARs respectively as 5, 5, 6, 5 and 5 articles.

From the Institute of Sport Pedagogy, 24 articles were published in total in five YEARs, which were distributed as follows: 3, 5, 6, 5 and 5 articles.

From the Institute of Mathematical Statistics, 6 articles were published in five YEARs, which were distributed as follows: 1, 0, 1, 3 and 1 article.

From the Cardiology Clinic of Tartu University Hospital, a total of 6 articles were published, which were distributed between the five YEARs as follows: 1, $1,2,1$ and 1 article.

The first authors from the University of Tartu published 81 articles in five YEARs; the first authors from the 7 subunits of TU Hospital 13, from the Estonian Naturalists' Society 3 articles, and from Baer Museum 1 article.

Part $\mathbf{b}$ of Table 8 shows that the first authors working in institutions of Tallinn published a total of 27 articles in five YEARs, which were distributed between the years as follows: 8, 9, 3, 3 and 4 articles.

From the Institute of History situated in Tallinn, there were 9 articles, which are distributed between the five YEARs as follows: 1, 5, 1, 1 and 1 article.

From the Estonian Institute of Cardiology, there were 8 articles, which are distributed between the five YEARs as follows: $3,1,1,1$ and 2 articles.

The authors from Tallinn Nõmme Children's Hospital published 5 articles which are distributed between the five YEARs as follows: 2, 1, 0, 1 and 1 articles.

The first authors from these three Tallinn institutions published a total of 22 articles in five YEARs; the first authors from the remaining four Tallinn institutions (Estonian Bureau of Medical Statistics, Institute of Experimental and Clinical Medicine, Informatics Department of the Ministry of Social Affairs and Health Protection Inspectorate) published a total of 5 articles.

Tables 3-7 show that 56 researchers in total were the first authors of 125 articles in five Yearbooks of the Estonian Anthropometric Register.

In addition, question arises how many of the 56 researchers were the only authors of the articles, who were the first authors and also co-authors of other articles and how many researchers were only co-authors of articles. 
The answer to these questions will be given in the next part of the overview. All the authors of the articles published in Estonian in five Yearbooks of the Estonian Anthropometric Register deserve attention, as they did their best to preserve and develop Estonian as the research language in anthropology, beginning more than 20 years ago.

\section{REFERENCES}

1. Eesti Antropomeetriaregistri Aastaraamat 1998 (1998). Tartu.

2. Eesti Antropomeetriaregistri Aastaraamat 1999 (1999). Tartu.

3. Eesti Antropomeetriaregistri Aastaraamat 2000 (2000). Tartu.

4. Eesti Antropomeetriaregistri Aastaraamat 2001 (2001). Tartu.

5. Eesti Antropomeetriaregistri Aastaraamat 2002 (2002). Tartu.

6. Kasmel J., Kasmel T. (2017). On preservation and development of Estonian as a research language in anthropology - the role of the Yearbooks of the Estonian Anthropometric Register (1998-2002) in it. Part I. Papers on Anthropology XXVI/1, 28-40.

\section{Address for correspondence:}

Jaan Kasmel

Centre for Physical Anthropology

University of Tartu

Struve 2, Tartu 51003, Estonia

Email: jaanjkasmel@hot.ee 